\title{
Stratigraphic Controls on Carbonate Evaporite Stratigraphy - Importance to Hydrocarbon Exploration: Examples from Middle Eastern Oil Fields and Their Response to Plate Tectonic Cycle, Climate, Basin Position and Sea Level
}

\author{
Christopher G. St. C. Kendall (University of South Carolina, USA, <kendall@sc.edu>)
}

Paleozoic, Mesozoic through Cenozoic sedimentary fill of the Tethys southern margin is subdivided stratigraphically by the beat of second- and third-order changes in eustasy, tectonic movement, sediment supply and Wilsonian cycles of plate movement. This northeastern flank of Gondwanaland extends from the Arabian Plate through Zagros and Taurus Mountains, Levant and North Africa. Regional chronostratigraphic charts and crosssections detail products of these processes and major petroleum production from carbonates and evaporites interbedded with clastic sequences; with flatter-lying horizons in Arabia, folded in the Zagros and Taurus Mountains of Iran and Turkey, wrenched margin through the Levant and disrupted block-faulted terrains in North Africa from Egypt through Libya.

In Arabia during late Paleozoic and Mesozoic deposition was in tropical settings and on an extensional passive Tethyan margin, which by the late Cretaceous to Tertiary was a foreland basin flanking the Zagros and Taurus uplift. Contrasting deposition on the North African plate also occurred in tropical settings, but followed an extensional passive margin through late Paleozoic, to Mesozoic, and Tertiary.

Recent advances in sequence stratigraphy provide a detailed and flexible framework to track and predict the distribution of evolving sedimentary facies on smaller spatial and temporal scales to determine future plays and define existing reservoirs. Tectonic mega-sequence events governed low frequency accommodation of sedimentary fill interrupted by surfaces formed by periods of non-deposition, and/or unconformities. Maximum flooding surfaces (mfs) express the maximum regional transgressions of fluctuations in eustasy. Both surfaces provide chronostratigraphic order to sedimentary fill dated by radiometric and biologic markers. 